\title{
Finansal Gelişmenin Gelir Eşitsizliği Üzerindeki Etkileri: Finansal Kuznets Eğrisi Hipotezi Türkiye İçin Geçerli mi?
}

\section{Ŭ̆ur Korkut PATA ${ }^{1}$}

\begin{tabular}{ccc}
\hline Geliş Tarihi/ Received & Kabul Tarihi/ Accepted & Yayın Tarihi// Published \\
19/11/2019 & $25 / 06 / 2020$ & $15 / 07 / 2020$ \\
\hline Citation/Atıf: Pata, U. K., (2020), Finansal Gelişmenin Gelir Eşitsizliği Üzerindeki Etkileri: \\
Finansal Kuznets Eğrisi Hipotezi Türkiye İçin Geçerli mi?, Atatürk Üniversitesi İktisadi ve İdari \\
Bilimler Dergisi, 34(3): 809-828, DOI: 10.16951/atauniiibd.648695 \\
\hline
\end{tabular}

Öz: Finansal gelişme bireylerin finansal kaynaklara daha iyi bir şekilde erișmesini sağlamaktadır. Finansal kaynaklara erişimin artması ile beraber gelir düzeylerinde de artış yaşanmaktadır. Gelir düzeyindeki artışın bireyler arasında eşit olarak paylaştırılması önemli bir araştırma konusudur. Gelir eşitsizliği genelde Gini katsayısı ile ölçülmektedir. Bu çalışma Türkiye için 1987-2016 döneminde finansal gelişme, enflasyon, kentleşme, kişi başına düşen gayrisafi sabit sermaye stoku ve Gini katsayısı arasındaki ilişkileri Bayer-Hanck birleşik eş-bütünleşme testi, kanonik eş-bütünleşme regresyonu (CCR) ve tam değiştirilmiş en küçük kareler (FMOLS) tahmincileri ile incelemeyi amaçlamaktadır. Bayer-Hanck testinin sonuçları bu değişkenlerin eşbütünleşik olduğunu göstermektedir. CCR ve FMOLS tahmincileri ile elde edilen uzun dönem katsayıları enflasyon ve sabit sermaye stokunun gelir eşitsizliğini arttırdığını, kentleşmenin ise bu eşitsizliği azalttığını belirtmektedir. Ayrıca finansal gelişmenin pozitif katsayısı ve finansal gelişmenin karesinin negatif olarak belirlenen katsayısı finansal Kuznets eğrisi hipotezinin geçerli olduğunu doğrulamaktadır.

Anahtar Kelimeler: Gelir Eşitsizliği, Enflasyon, Kentleşme, Finansal Kuznets Eğrisi.

\section{The Effects of Financial Development on Income Inequality: Is the Financial Kuznets Curve Hypothesis is Valid for Turkey?}

Abstract: Financial development enables individuals to have better access to financial resources. As the access to financial resources increases, income levels also increase. Equal distribution of the increase in income among individuals is an important research topic. Income inequality is generally measured by the Gini coefficient. This paper aims to investigate the relationship between financial development, inflation, urbanization, per capita gross fixed capital formation and Gini coefficient for Turkey, using Bayer-Hanck combined cointegration test, canonical cointegrating regression (CCR) and fully modified least square (FMOLS) estimators from 1987 to 2016. The results of the Bayer-Hanck test reveal that these variables are cointegrated. The long-term coefficients obtained from the CCR and FMOLS estimators demonstrate that inflation and gross fixed capital formation increases income inequality, whereas urbanization decreases the inequality in the long-term. Furthermore, the positive coefficient of financial development and the negative coefficient of the square of financial development confirm that the financial Kuznets curve hypothesis is valid for Turkey.

Keywords: Income Inequality, Inflation, Urbanization, Financial Kuznets Curve.

${ }^{1}$ Dr., Osmaniye Korkut Ata Üniversitesi, İktisadi ve İdari Bilimler Fakültesi, İktisat Bölümü, https://orcid.org/0000-0002-2853-4106 
Finansal Gelişmenin Gelir Eşitsizliği Üzerindeki Etkileri: Finansal Kuznets Ĕgrisi Hipotezi Türkiye İçin Geçerli mi?

\section{Background}

\section{EXTENDED SUMMARY}

Income inequality is an important problem for countries. Various measures are taken to regulate income distribution. When taking these measures, it is important to identify the factors affecting income distribution. Various macroeconomic variables such as financial development, urbanization, inflation, unemployment and economic growth can affect income distribution. Greenwood and Jovanovic (1990) stated that there would be an inverted U-shaped relationship between income inequality and financial development, and this relationship was described as the financial Kuznets curve. This study aims to empirically test the validity of the financial Kuznets curve in Turkey.

\section{Research Questions}

The financial Kuznets curve hypothesis is valid for Turkey?

Does financial development and urbanization reduce income inequality?

Does inflation and capital stock increase income inequality?

\section{Methodology and Data}

In this study, Bayer and Hanck (2013) cointegration test was used to analyze the cointegration relationship between capital stock, inflation, urbanization and income inequality. This test can provide more effective results by combining four separate cointegration test statistics. After testing the cointegration relationship between the variables, equations 1 and 2 were estimated using fully modified ordinary least squares (FMOLS) and canonical cointegrating regression (CCR) estimators to obtain long-term coefficients.

$$
\begin{aligned}
& \operatorname{lnGINI}_{\mathrm{t}}=9_{0}+\vartheta_{1} \operatorname{lnFD}_{\mathrm{t}}+\vartheta_{2} \operatorname{lnFD1}_{\mathrm{t}}^{2}+\vartheta_{3} \operatorname{lnINF}_{\mathrm{t}}+\vartheta_{4} \operatorname{lnK}_{\mathrm{t}}+\vartheta_{5} \operatorname{lnURB}_{\mathrm{t}}+\mathrm{u}_{\mathrm{t}} \\
& \operatorname{lnGINI}_{\mathrm{t}}=\alpha_{0}+\alpha_{1} \operatorname{lnFD} 2_{\mathrm{t}}+\alpha_{2} \operatorname{lnFD} 2_{\mathrm{t}}^{2}+\alpha_{3} \operatorname{lnINF}_{\mathrm{t}}+\alpha_{4} \operatorname{lnK}_{\mathrm{t}}+\alpha_{5} \operatorname{lnURB}_{\mathrm{t}}+\mathrm{e}_{\mathrm{t}}
\end{aligned}
$$

In equations 1 and 2, the GINI variable, which is an indicator of income inequality, is obtained from SWIID 7.0 data set created by Solt (2018). Data for all remaining variables were compiled from the World Bank Development Indicators (2019). Among these variables, FD1: domestic credit to private sector (\% of GDP), FD2: domestic credit to private sector by banks (\% of GDP), INF: consumer price index (\%), F: per capita gross fixed capital stock (2010 constant USD) and URB: the share of urban population in total population (\%). In equations, if $\vartheta_{1}-\alpha_{1}>0$ and $\vartheta_{2}-\alpha_{2}<0$, it is decided that the financial Kuznets curve hypothesis is valid.

\section{Results and Conclusions}

The results of the Bayer-Hanck test show that there is a cointegration relationship between the variables. According to the results of both estimators in Table 1, statistically significant positive coefficients of FD and negative coefficients of $\mathrm{FD}^{2}$ indicate that the financial Kuznets curve hypothesis is valid for Turkey. 
Uğur Korkut PATA

Table 1: FMOLS and CCR Estimation Results

\begin{tabular}{|c|c|c|c|c|}
\hline Estimator & \multicolumn{2}{|c|}{ FMOLS } & \multicolumn{2}{|c|}{ CCR } \\
\hline Variable & Eq 1 & Eq 2 & Eq 1 & Eq 2 \\
\hline $\operatorname{lnFD} 1, \operatorname{lnFD} 2$ & $0.448 * * *$ & $0.509 * * *$ & $0.398 * * *$ & $0.407 * * *$ \\
\hline $\ln (\mathrm{FD} 1)^{2}, \ln (\mathrm{FD} 2)^{2}$ & $-0.074 * * *$ & $-0.084 * * *$ & $-0.067 * * *$ & $-0.071 * * *$ \\
\hline $\operatorname{lnINF}$ & $0.009 * *$ & $0.008 * *$ & $0.009 * *$ & $0.011 * *$ \\
\hline $\operatorname{lnK}$ & $0.082 * * *$ & $0.074 * * *$ & $0.095 * * *$ & $0.108 * * *$ \\
\hline $\operatorname{lnURB}$ & $-0.213 * * *$ & $-0.202 * * *$ & $-0.240 * * *$ & $-0.244 * * *$ \\
\hline Constant & $3.347 * * *$ & $3.263 * * *$ & $3.446 * * *$ & $3.359 * * *$ \\
\hline Jarque-Bera & $\begin{array}{l}1.598 \\
(0.449)\end{array}$ & $\begin{array}{l}1.685 \\
(0.430)\end{array}$ & $\begin{array}{l}1.703 \\
(0.426)\end{array}$ & $\begin{array}{l}2.097 \\
(0.350)\end{array}$ \\
\hline
\end{tabular}

Note: The optimal lag lengths were determined by SIC. $* * *$ and $* *$ denote significant at $1 \%$ and $5 \%$ levels, respectively.

The results of the FMOLS method show that a $1 \%$ increase in inflation and per capita capital stock increases the income inequality by $0.009 \%$ and $0.082 \%$, respectively. Although these coefficients are not high, it can be said that the increases in inflation and capital stock adversely affect the income distribution. Finally, a $1 \%$ increase in urbanization reduces income inequality by $0.202 \%$ to $0.244 \%$. In light of findings, we concluded that urbanization and financial development are two important factors in order to ensure income distribution for Turkey.

\section{Giriş}

Günümüzde küreselleşme ile birlikte birçok ülkede finansal gelişme artarak devam etmektedir. Finansal gelişme temel olarak bankacılık ve hisse senedi piyasaları ile birlikte, finansal aktiflere yatırım yapılabilen, aynı zamanda borçlanmak isteyenlere çeşitli fon ve kredilerin sağlandığı bir sektörü oluşturmaktadır. Bu sektörde hem iç hem de dış kaynaklar yer almaktadır. Finansal gelişme ile birlikte tasarruf sahipleri fonlarını daha etkin kullanmakta, böylece tasarruflar yatırımlara dönüştürülerek ekonomi daha iyi bir performans gösterebilmektedir (Argun, 2016: 62). Genel itibariyle finansal gelişmenin daha fazla fon ve kredi ile birlikte yatırımları ve istihdamı arttırarak ekonomik büyüme üzerinde olumlu bir etki sağladığı düşünülmektedir. Ancak bu olumlu etkilerin yanı sıra, bir ülkede dış kaynaklara bağımlılığın artması finansal gelişmenin kusurlu kısmı olarak görülmektedir. Finansal gelişme borçlanmayı arttırdığından dolayı ekonomik büyüme üzerinde olumsuz etkilere sebebiyet verebilmektedir (Moosa, 2016: 363). Finansal gelişme nedeniyle hane halkının ve kurumların borçları artmakta, artan bu borçlar finans sektörüne kar olarak yansımaktadır. Ancak bazı ekonomilerde finans sektöründeki kurumlar elde ettikleri bu karlar ile yeni fiziksel sermaye yatırımı gerçekleştirmemekte, kar oranını arttırmak için kredi, döviz ve çeşitli hisse senedi piyasalarında işlem yapmaktadırlar. Bu durum ise reel sektör üzerinde olumsuz bir etkiye sebebiyet verebilmektedir. 2008 krizinden sonra birçok alanda finans sektörünün topluma yararları ve zararları tartışılmaya başlanmıştır. (Jauch ve Watzka, 2016: 292). 
Finansal Gelişmenin Gelir Eşitsizliği Üzerindeki Etkileri: Finansal Kuznets Ĕgrisi Hipotezi Türkiye İçin Geçerli mi?

Ekonomik büyüme kadar gelir dağılımındaki adaletsizlik de toplumların gelişmesi için göz önünde bulundurulan önemli bir makroekonomik unsurdur. Gelir eşitsizliği, özellikle gelişmekte olan ülkelerin kalkınma ve refah ekonomisi için ekonomik büyümeye ve refah düzeyindeki artışa engel olan büyük bir ilgi alanıdır (Tan ve Law, 2012: 552). Gelir düzeyi kişilerin refah seviyesini etkileyen mühim etkenlerden biridir. Bir ülkede yaratılan gayrisafi yurtiçi hasılanın adil bir şekilde dağıtılması önem arz etmektedir. Bireyler gelir düzeylerindeki göreceli artışa da önem vermektedir. Bir kesim çok zenginleşirken, diğer kesim pastadan daha az pay aldığında bu durum huzursuzluğa yol açmaktadır. Gelir artışı tabana yayılmadığı sürece çeşitli toplumsal sorunların oluşması kaçınılmazıdır. Gelir eşitsizliği yüksek büyüme oranları hedefleyen ülkelere zarar vermektedir. Bu eşitsizlik suç ve şiddet gibi toplumsal sorunlar yaratmaktadır. Tüm bu nedenlerden dolayı gelir dağılımdaki eşitsizliği etkileyen faktörleri belirlemek ve bu eşitsizliğin giderilmesini sağlamak oldukça önemlidir. Ekonomik gelişim, finansal gelişme, kamu harcamaları, eğitim, enflasyon, nüfus artışı ve dışa açılılık gelir eşitsizliğini etkileyen en önemli faktörlerdendir (Rehman vd., 2008: 2).

Bu çalışma Türkiye'de finansal Kuznets eğrisinin geçerliliğini test etmeyi amaçlamaktadır. Türkiye 2001 krizi sonrasında gerçekleştirdiği yapısal reformlar ile birlikte daha güçlü bir bankacılık ve finansal yapı sağlamıştır. Ülkedeki gelir eşitsizliği özellikle 2007 yılından itibaren önemli ölçüde azalmaya başlamıştır.

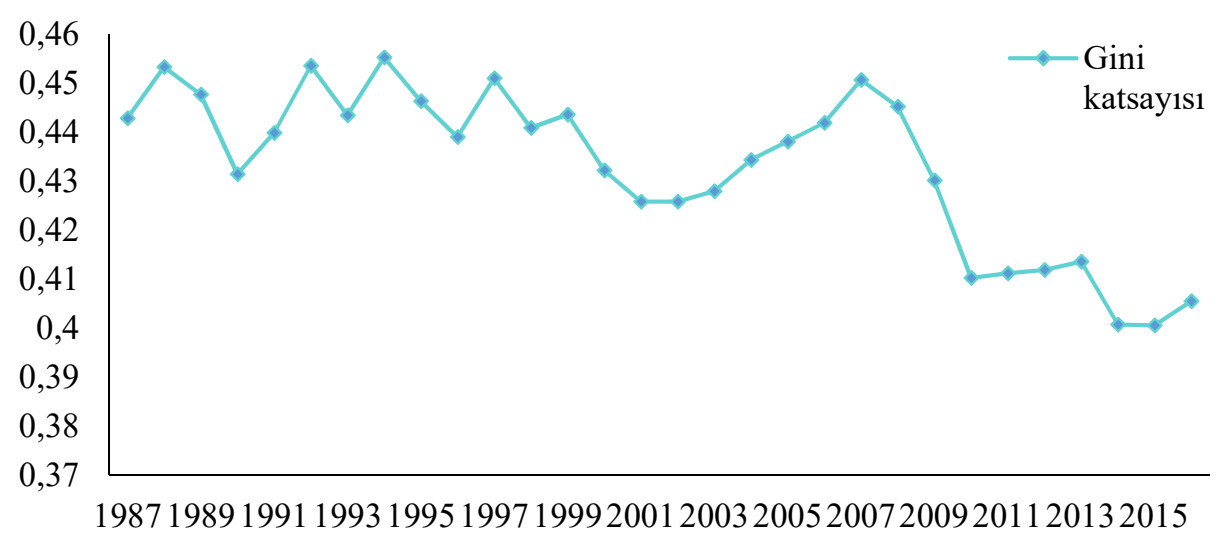

Kaynak: Solt, 2018.

Şekil 1: Türkiye'de 1987-2016 Döneminde Gelir Eşitsizliği

Şekil 1'de Türkiye'de 1987-2016 dönemine ait Gini katsayıs1 gösterilmektedir. Türkiye'de 1987 'den 2001 'e kadar süren gelir dağılımındaki iyileşme, 2001 yılından 2007 yılına kadar bozulma göstermeye başlamıştır. Ancak 2007 yllında itibaren gelir eşitsizliği azalmış ve 2014 yılında Gini katsayısı 0,40'lara gerilemiştir. 2015 ve 2016 yılında ise az da olsa gelir dağglımda bir kötüleşmenin olduğu gözlemlenmektedir. Yine de Türkiye'de gelir 
eşitsizliğini belirten Gini katsayısı ilgili dönemde en çok 0,45 değerini almış ve son yıllarda 0,40'lara yakın bir seyir izlemiştir. Genel itibariyle Türkiye'de 1980'li yıllara göre gelirin daha adil bir şekilde dağılım gösterdiği söylenebilir.

Türkiye gibi gelişmekte olan bir ülke için gelir eşitsizliğini gidermek oldukça önemlidir. Literatürde sadece Türkiye için bu hipotezi Destek vd. (2017)'i sınamışlardır. Yazarların çalışmasından farklı olarak bu çalışmada kentleşme ve sermaye stokunun gelir eşitsizliği üzerindeki etkileri farklı bir ekonometrik yöntem uygulanarak Türkiye için ilk kez analiz edilmiştir. Ayrıca iki farklı finansal gelişme göstergesi kullanılarak bulguların finansal gelişme göstergelerine göre değişip değişmediği de incelenmiştir. Her iki açıdan çalışmanın mevcut literatüre katkı sağlaması ve Türkiye'de finansal Kuznets eğrisinin geçerliliğini hakkında yeni tartışmalara olanak tanıması beklenmektedir.

Türkiye'de finansal gelişme ve gelir eşitsizliği arasındaki ilişkileri finansal Kuznets eğrisi hipotezi kapsamında analize enflasyon, sabit sermaye stoku ve kentleşmenin etkilerini de dahil ederek incelemeyi amaçlayan bu çalışmada giriş bölümünü takiben ikinci bölümde gelir eşitsizliğine etki eden unsurlar ve Finansal Kuznets eğrisi açıklanmış, üçüncü bölümde konu ile ilgili gerçekleştirilen ampirik çalışmaları kapsayan literatüre yer verilmiştir. Dördüncü bölümde çalışmada kullanılan veri seti ile yöntemler tanıtılmış ve beşinci bölümde bu yöntemlerden elde edilen bulgular sunulmuştur. Son olarak sonuç bölümünde ilgili değişkenlerden elde edilen bulgular özetlenerek politika önerilerine yer verilmiştir.

\section{Finansal Kuznets Eğrisi ve Gelir Eşitsizliğine Etki Eden Unsurlar}

Kuznets (1955) gelir düzeyi arttıkça ilk başta gelir eşitsizliğini artacağını, sonra ise azalacağını belirtmiştir. Ters U şekildeki bu ilişki Kuznets-eğrisi olarak nitelendirilmiştir. Zamanla bu eğri başka değişkenler arasındaki ilişkilere de uyarlanmıştır. Panayotou (1993) kişi başına düşen gelir düzeyi ile çevre kirliliği göstergeleri arasındaki ilk önce doğru, sonra ise zıt yönlü ters-U şeklindeki ilişkiyi çevresel Kuznets eğrisi olarak adlandırmıştır. Greenwood ve Jovanovic (1990) ise gelir eşitsizliği ile finansal gelişme arasında benzer bir ilişki olacağını ifade etmiş ve bu ilişkiyi finansal Kuznets eğrisi olarak nitelendirilmiştir.

Ekonomik gelişimin başlangıcında gelire göre sabit maliyeti yüksek olduğundan dolayı az sayıda insan finansal araçları kullanmaktadır. Zamanla finans sektörü gelişmekte, ekonomik büyüme ve eşitsizlik artmaktadır. Ekonomi olgunlaştıkça daha fazla insan finansal aracıları kullanmakta, bu durum ise büyümeyi maksimize etmekte ve eşitsizliği azaltmaktadır (Nikoloski, 2013: 898). Gelişimin ilk aşamalarında, bir ekonominin finansal piyasaları neredeyse yok denecek kadar yavaş büyümektedir. Finansal büyüme, ekonomi büyüme döngüsünün orta aşamasına doğru yaklaşıldıkça oluşmaya başlamaktadır. $\mathrm{Bu}$ noktada ekonomik büyüme ve tasarruf oranları yükselirken, zengin ve yoksul arasındaki gelir dağılımındaki fark açılmaktadır (Greenwood ve Jovanovic, 1990: 
Finansal Gelişmenin Gelir Eşitsizliği Üzerindeki Etkileri: Finansal Kuznets Ĕgrisi Hipotezi Türkiye İçin Geçerli mi?

1078). Ekonomi olgunlaşınca finansal faaliyetler artmakta ve son aşamada tasarruf oranları düşmekte, gelir ise bireyler arasında yakınsamaktadır. Zamanla gelir düzeyi düşük aileler de finans sektöründeki gelişim ile birlikte kredilere ve çeşitli kaynaklara erişip gelir düzeylerini arttırabilmektedir. Diğer bir deyişle, gelişimin ilk aşamasında finansal piyasalardan toplumun sadece zengin kesimi faydalanabilmekte ve kar elde edebilmektedir. Ekonomik gelişimin ilerleyen aşamalarında ise toplumun gelir düzeyi düşük olan kesimi de finansal piyasalara erişebilmekte ve böylece finansal gelişme doğrudan toplumun daha büyük bir kısmına yardım etmektedir. Tüm bu nedenlerden dolayı finansal gelişme ile gelir dağılımdaki eşitsizlik arasında ters $\mathrm{U}$ şeklinde bir ilişkinin olması beklenebilmektedir.

Finansal sistem, bir toplumda kimin işe başlayıp başlayamayacağını, kimin eğitim giderlerini karşılayıp karşılayamayacağını ve kimin ekonomik isteklerini gerçekleştirip gerçekleştiremeyeceğini belirleyebilmektedir. Ayrıca finansal gelişme sermayenin tahsisini etkileyerek hem ekonomik büyüme oranını hem de emek talebini değiştirmekte ve böylece yoksulluk ile gelir dağılımı üzerinde derin bir etkiye sahip olabilmektedir (Demirgüç-Kunt ve Levine, 2009: 288). Geniş kapsamlı kurulan bir finans sektörü ucuz krediler ile çeşitli insanlara girişimcilik faaliyetleri yürütmeyi sağlamakta ve bu durum iş imkanları oluşturarak toplumun refahını arttırmaktadır (Azam ve Raza, 2018: 89). Finansal gelişimin yeterli düzeyde olmaması gelir dağılımında daha yüksek bir adaletsizliğe sebebiyet vererek yoksul kesimi zengin kesime göre daha fazla zarara uğratmaktadır (Ang, 2010). Kısıtlı kredi imkanları göz önüne alındığında, asimetrik bilgi, sözleşme uygulama maliyetleri ve işlem maliyetleri gibi finansal piyasa kusurlarından en fazla gelir düzeyi düşük girişimciler etkilenebilmektedir. Finans sektörü büyüdükçe daha önce borçlanma imkanı olmayan yoksul kesim de kredi alabilir hale gelebilir (Clarke vd. 2006: 578). Ülkedeki artan finansal gelişme, özellikle gelir düzeyi görece olarak düşük kesimin üzerindeki bu finansman kısıtlamasını gevşetmeye ve onlara finansmana daha fazla erişim sağlamaya yardımcı olacaktır. Dolayısıyla, finansal gelişme, sermayenin üretken projelere tahsis edilmesinden dolayı büyümeyi artıracak, yoksulluk ve eşitsizliği azaltacaktır (Canavire-Bacarreza ve Rioja, 2008: 3).

Finansal kaynaklara daha kolay erişimle beraber gelir düzeyi düşük kesimlerin çocuklarının ve aile bireylerinin beşeri sermayelerini artırmak için eğitim alma olanakları, sağlık hizmetlerinden yararlanma imkanları artmaktadır. Ayrıca bu durum yatırımları artarak nüfusun gelir düzeyi düşük kesimlerine iş imkanı sağlanmaktadır (Shahbaz vd., 2015: 358; Destek vd. 2017: 154). Aktif ve iyi gelişmiş bir finans sektörü daha ucuz kredi sağlayabilmekte ve bu sayede iş olanakları yaratan ve toplumun refahını arttıran girişimcilik faaliyetlerini geliştirmeye yardımcı olan çeşitli kişilerin finansal hizmetlere erişimini kolaylaştırmaktadır (Younsi ve Bechtini, 2018: 2).

Enflasyon artışının genel itibariyle gelir dağılımı üzerinde olumsuz bir etkisinin olduğu varsayılmaktadır. Yüksek enflasyon oranları yoksul ve orta 
kesime gelir düzeyi yüksek kesimden daha fazla zarar vererek gelir eşitsizliğini arttırabilmektedir (Rehman vd. 2008: 4).

Kentleşme de finansal gelişme, sermaye ve enflasyon gibi gelir eşitsizliğini etkileyebilmektedir. Kentleşmenin çevre üzerindeki etkileri birçok çalışma ile incelenmiştir. Ancak kentleşmenin yoksulluk ile ilişkisi hakkında bilinenler oldukça kısıtlıdır. $\mathrm{Bu}$ nedenle kentleşmenin yoksulluk üzerindeki etkilerinin incelenmesi önem arz etmektedir (Cobbinah vd., 2015: 19). Sanayileşme ve kentleşmenin çalkantılı ilk süreçleri geçildikten sonra, düşük gelirli grupların ekonomik konumunu güçlendirmek için çeşitli güçler bir araya gelmektedir (Kuznets, 1955: 18). Bir süre sonra, kentsel nüfusun artan bir oranının "yerel" olduğu, yani kırsal alanlardan ziyade şehirlerde doğduğu ve bu nedenle ekonomik yaşama hazırlıkta şehir hayatının olanaklarından daha fazla yararlanabileceği gerçeği mücadele, örgütlenme ve adaptasyon için daha iyi bir şans doğurmaktadır. Böylece daha eğitimli bireyler ile gelir eşitsizliği azalmaya başlayabilmektedir. Kırsal alanlarda yaşayan nüfusun elde ettiği gelir kentsel alanlara göre çoğunlukla daha düşük olmaktadır. Kentlerde gelir düzeyinin artmasını sağlayabilecek iş, eğitim ve benzeri birçok sosyoekonomik imkan kırsal kesime göre daha fazladır. Dolayısıyla kırdan kente göç eden bireylerin kentleşme ile birlikte gelir seviyelerinin artması beklenmektedir. Machado vd. (2015) Brezilya' da yüksek kentleşme oranına sahip bölgelerde kişi başına düşen gelir düzeyinin daha yüksek olduğunu ve bu bölgedeki insanların daha uzun yıllar eğitim alabildiklerini belirtmişlerdir. Yazarlar ayrıca kentleşmenin yoğun olduğu bölgelerde genel ve zihinsel olarak sağlık hizmetlerine erişim için daha fazla imkan olduğunu ve bu bölgelerde gelir eşitsizliğinin daha az olduğunu ifade etmişlerdir.

\section{Literatür Araştırması}

Finansal gelişmenin ekonomik büyüme ile etkileşimi hakkında yoğun bir ampirik ve teorik literatür mevcuttur. Türkiye için finansal gelişmenin ekonomik büyümeyi olumlu yönde etkilediğini literatürdeki birçok çalışmada ifade edilmiştir (Aslan ve Küçüksoy, 2006; Altıntaş ve Ayrıçay; 2010; Pata ve Ağaca, 2018). Ancak bu gelişmenin gelir eşitsizliği üzerindekini etkisini hem Türkiye hem de diğer ülkeler için inceleyen çalışma sayısı göreceli olarak oldukça azdır.

Finansal gelişme ve gelir eşitsizliği arasındaki ilişki üç temel hipotez ile ifade edilebilir. Greenwood ve Jovanovic (1990) finansal gelişmenin ilk başta gelir eşitsizliğini arttırdığını, ekonomik gelişimin ilerleyen aşamalarında ise bu durumun tersine döndüğünü belirtmişlerdir. İki değişken arasındaki bu ilişki tersU hipotezi (finansal Kuznets eğrisi hipotezi) olarak nitelendirilmektedir. Banerjee ve Newman (1993) ve Galor ve Zeira (1993) finansal gelişmenin gelir eşitsizliğini azalttığını, iki değişken arasındaki ilişkinin lineer olduğunu ifade etmişlerdir. Finansal gelişme ile gelir eşitsizliği arasındaki bu negatif ilişki eşitsizlik-daralma hipotezi olarak nitelendirilmektedir. Son olarak finansal sektör geliştikçe teminat sağlayamayan yoksul kesim ihmal edilebilir. Bunun sonucunda 
Finansal Gelişmenin Gelir Eşitsizliği Üzerindeki Etkileri: Finansal Kuznets Ĕgrisi Hipotezi Türkiye İçin Geçerli mi?

finansal gelişim sağlansa da yoksul kesim kentlere göç edememekte, iyi bir eğitim alamamakta ve girişimcilik faaliyetleri ile uğraşamamaktadır. Eğer böyle bir durum var ise finansal gelişme ile gelir dağılımdaki eşitsizlik arasında pozitif bir ilişki söz konusu olacaktır. Bu ilişki ise eşitlik-genişleme hipotezi olarak adlandırılmaktadır (Clarke vd. 2006: 580-581).

2000'li yıllara gelindiğinde finansal gelişme ve gelir eşitsizliği arasındaki ilişkiyi inceleyen çalışmalar artarak devam etmiştir. Bu çalışmalardan;

Rehman vd. (2008) 1975-2002 döneminde 107 ülke için panel veri analizi kullanarak finansal gelişme ile gelir eşitsizliği arasında bir ilişki olmadığını belirlemişlerdir. Batuo vd. (2010) 1990-2004 döneminde 22 Afrika ülkesi için genelleştirilmiş momentler metodu (GMM) ile finansal gelişme arttıkça gelir eşitsizliğinin lineer bir şekilde azaldığını tespit etmişlerdir. Baligh ve Piraee (2012) 1973-2010 döneminde İran için ARDL sınır testi ile finansal gelişmenin gelir eşitsizliğini azalttığını belirlemişlerdir. Tan ve Law (2012) 1980-2000 döneminde gelişmekte olan 35 ülke için GMM yöntemi ile finansal gelişme ve gelir eşitsizliği arasında $\mathrm{U}$ şeklinde bir ilişki bulunduğu sonucuna varmışlardır. Hoi ve Hoi (2013) 2002-2008 döneminde Vietnam için panel sabit ve rassal etkiler modelleri ile eğitimin, ticari açıklığın ve finansal gelişmenin gelir eşitsizliğini azalttığını, enflasyon ve kişi başına düşen gelir düzeyindeki yükselişlerin ise bu eşitsizliği arttırdığını belirtmişlerdir. Tiwari vd. (2013) 19652008 döneminde Hindistan için ARDL sınır testi ile finansal gelişme, enflasyon ve gelir düzeyindeki artışın gelir eşitsizliğini arttırdığını tespit etmişlerdir. Doğan (2018) 1974-2014 döneminde Arjantin için Maki eş-bütünleşme testi ve DOLS tahmincisi ile finansal gelişme ve gelir eşitsizliği arasında U şeklinde bir ilişki olduğunu ve ayrıca ekonomik büyüme arttıkça gelir eşitsizliğinin azalacağını ortaya koymuştur. Satti vd. (2015) 1991-2001 döneminde Kazakistan için ARDL sınır testi ile finansal gelişme ve gelir eşitsizliği arasında $U$ şeklinde bir ilişki olduğunu belirlemiştir. Sehrawat ve Giri (2015) 1982-2012 döneminde Hindistan için ARDL sınır testi ile finansal gelişme, ekonomik büyüme ve enflasyonun gelir eşitsizliğini arttırdığını, ticari açıklığın ise bu adaletsizliği azalttı̆̆ını tespit etmişlerdir. Jauch ve Watzka (2016) 1960-2008 döneminde 138 gelişmiş ve gelişmekte olan ülke için havuzlanmış en küçük kareler yöntemi, GMM ve sabit etkiler modeli ile finansal gelişmenin gelir eşitsizliğini arttırdığını ve ayrıca enflasyon, hükümet harcamaları ve tarımın gelir eşitsizliği üzerinde önemli bir etkilerinin olmadığını belirlemişlerdir. Moosa (2016) 95 ülke için yatay kesit veri ile finansal gelişme ve gelir eşitsizliği arasında bir ilişki olmadığını ileri sürmüştür. Van Velthoven vd. (2019) 1975-2005 döneminde 85 ülke için panel sabit etkiler modeli ile finansal gelişmenin, finansal serbestleşmenin ve banka krizlerinin gelir eşitsizliğini arttırdığını belirlemiştir. Sonuç itibariyle bu 12 çalışmada finansal Kuznets eğrisinin geçerli olmadığı belirlenmiştir.

Yukarıda bahsi geçen çalışmaların aksine 9 çalışmada ilgili hipotezin geçerli olduğu tespit edilmiştir. Bu çalışmalardan; Clarke vd. (2006) 1960-1995 döneminde 83 ülke için panel veri regresyon analizi ile finansal gelişme ve gelir 
eşitsizliği arasında zayıf da olsa ters-U şeklinde bir ilişkinin olduğunu belirlemişlerdir. Nikoloski (2013) 1962-2012 döneminde 75 gelişmiş ve gelişmekte olan ülke için genelleştirilmiş momentler metodu (GMM), havuzlanmış en küçük kareler yöntemi ve sabit etkiler modeli ile ekonomik büyüme ve gelir eşitsizliği arasında da ters $U$ şeklinde bir ilişki bulunduğunu, enflasyon, sanayileşme ve hükümet harcamalarının ise gelir eşitsizliği üzerinde herhangi bir etkilerinin bulunmadığını tespit etmiştir. Shahbaz vd. (2015) 19652011 döneminde İran için ARDL sınır testi yaklaşımı ve vektör hata düzeltme model (VECM) ile küreselleşme ve gelir eşitsizliği arasında U-şeklinde bir ilişkinin olduğunu tespit etmişlerdir. Yazarlar ayrıca enflasyonun gelir dağılımı üzerinde olumsuz bir etkisinin olduğunu belirlemişlerdir. Argun (2016) 19892013 döneminde 10 ülke için rassal etkiler modeli ile gelir düzeyi ve gelir eşitsizliği arasında ters-U şeklinde bir ilişki olduğunu, enflasyon ve dış ticaretteki artışın ise gelir eşitsizliğini arttırdığı sonucuna ulaşmıştır. Topuz ve Dağdemir (2016) 1995-2011 döneminde 94 ülke için gerçekleştirdikleri GMM ile ekonomik büyümenin gelir eşitsizliğini arttırdığını, eğitim ve dışa açıklı̆̆ın ise bu adaletsizliği azalttığını belirtmişlerdir. Destek vd. (2017) 1977-2013 döneminde Türkiye için ARDL sınır testi yaklaşımı ve VECM ile hem kısa hem de uzun dönemde kamu harcamaları ve enflasyonundaki artışın gelir eşitsizliğini arttırdığı, ekonomik büyümenin ise gelir eşitsizliğini azalttığını belirlemiştir. Hepsağ (2017) 1961-2015 döneminde ABD, Almanya, İngiltere, İtalya ve Kanada için ARDL sınır testi, Shin eş-bütünleme testi ve DOLS tahmincisi ile ABD, İtalya ve Kanada'da finansal Kuznets eğrisi hipotezinin geçerli olduğunu belirlemiştir. Yazar ayrıca analize dahil edilen tüm ülkelerde gelir düzeyi ve gelir eşitsizliği arasında bir ilişki bulunmadığını ifade etmiş̧ir. Azam ve Raza (2018) 1989-2013 döneminde Endonezya, Malezya, Filipinler, Singapur ve Tayland için Pedroni ve Kao eş-bütünleşme testleri, sabit etkiler modeli, havuzlanmış en küçük kareler yöntemi, GMM ve Granger nedensellik testi ile enflasyonun gelir eşitsizliğini arttırdığı sonucuna ulaşmışlardır. Younsi ve Bechtini (2018) 19902015 döneminde Brezilya, Çin, Rusya, Hindistan ve Güney Afrika için havuzlanmış en küçük kareler yöntemi, sabit etkiler modeli ve GMM ile gelir düzeyi ile de gelir eşitsizliği arasında ters-U şeklinde bir ilişkinin var olduğunu tespit etmişlerdir.

Gerçekleştirilen ampirik çalışmalar neticesinde finansal Kuznets eğrisi hipotezinin geçerliliği hakkında herhangi bir görüş birliğine varılamamıştır. Mevcut çalışmalarda kullanılan yöntemler, dönemler, ülke ve ülke grupları farklılık arz etmektedir. Literatürde Türkiye için finansal Kuznets eğrisi hipotezini sınayan Destek vd. (2017) haricinde bir çalışma yazarın bildiği kadarıyla bulunmamaktadır.

\section{Veri Seti, Model ve Ampirik Yöntem}


Finansal Gelişmenin Gelir Eşitsizliği Üzerindeki Etkileri: Finansal Kuznets Ĕgrisi Hipotezi Türkiye İçin Geçerli mi?

Türkiye'de 1987-2016 döneminde finansal Kuznets eğrisi hipotezinin geçerliliğinin sınandığı bu çalışmada temel alınan kuadratik yapıdaki denklemler aşağıda gösterilmektedir.

$$
\begin{aligned}
& \operatorname{lnGINI}_{\mathrm{t}}=9_{0}+\vartheta_{1} \operatorname{lnFD} 1_{\mathrm{t}}+\vartheta_{2} \operatorname{lnFD} 1_{\mathrm{t}}^{2}+\vartheta_{3} \operatorname{lnINF}_{\mathrm{t}}+\vartheta_{4} \operatorname{lnK}_{\mathrm{t}}+\vartheta_{5} \operatorname{lnURB}_{\mathrm{t}}+\mathrm{u}_{\mathrm{t}} \\
& \operatorname{lnGINI}_{\mathrm{t}}=\alpha_{0}+\alpha_{1} \operatorname{lnFD} 2_{\mathrm{t}}+\alpha_{2} \operatorname{lnFD} 2_{\mathrm{t}}^{2}+\alpha_{3} \operatorname{lnINF} \mathrm{n}_{\mathrm{t}}+\alpha_{4} \operatorname{lnK}_{\mathrm{t}}+\alpha_{5} \ln \operatorname{lnRB}_{\mathrm{t}}+\mathrm{e}_{\mathrm{t}}
\end{aligned}
$$

Denklem 1 ve 2 'de gelir eşitsizliğinin göstergesi olan GINI değişkenini ifade eden indeks, Solt (2018) tarafından oluşturulan SWIID 7.0 veri setinden elde edilmiştir. Geriye kalan tüm değişkenlere ait veriler Dünya Bankası Kalkınma Göstergeleri (2019)'nden derlenmiştir. Bu değişkenlerden finansal gelişmenin göstergesi olarak FD1: özel sektöre bankalar tarafından sağlanan yerel kredilerin GSYH içindeki payını (\%), FD2: özel sektöre tarafından toplam yerel kredilerin GSYH içerisindeki payını, INF: tüketici fiyatları ile enflasyon oranını (yıllık \%), K: kişi başına düşen gayrisafi sabit sermaye stokunu (2010 sabit fiyatları ile ABD doları cinsinden) ve URB: kentsel nüfusun toplam nüfus içerisindeki payını (\%) ifade etmektedir.

Denklemlerde $\vartheta_{1}-\alpha_{1}>0$ ve $\vartheta_{2}-\alpha_{2}<0$, ve bu katsayılar istatistiksel olarak anlamlı olduğu durumda finansal gelişme ve gelir eşitsizliği arasında ters-U şeklinde bir ilişkinin varlığını ifade eden finansal Kuznets eğrisi hipotezi geçerlidir. Enflasyonun gelir dağılımını bozucu bir etkisi olduğundan ötürü $\vartheta_{3}-\alpha_{3}$ katsayılarının pozitif olması beklenmektedir. Sermaye ve kentleşmenin gelir dağılımı üzerindeki etkileri ülkelerin gelişmişlik düzeylerine göre farklılık arz edebilmektedir.

\subsection{Bayer-Hanck Eş-bütünleşme Testi}

Birinci farkında bütünleşik olan iki değişken arasında eş-bütünleşme ilişkileri ilk kez Engle ve Granger (1987)'nin (EG) geliştirmiş olduğu hata terimine dayalı test ile incelenmeye başlanmışıtır. Johansen (1988) (JO) ikiden daha fazla değişken arasındaki eş-bütünleşme ilişkisinin vektörlere dayalı tespit edilebildiği bir test geliştirmiştir. Boswijk (1994) (BO) ve Banerjee vd. (1998) $(\mathrm{BDM})$ ise sirasiyla F- ve t-testleri uygulanan hata düzeltme modeli temelli testler ile eş-bütünleşmenin varlığını sınamışlardır.

Her bir eş-bütünleşme testi ile ayrı sonuçlar elde edebilmek mümkündür. Bu nedenle değişik testler ile elde edilen eş-bütünleşme bulgularının güvenilirliği tartışmaya açıktır. Bayer ve Hanck (2013) bu dört ayrı testi birleştirerek Fisher (1932)'in formülasyonuna dayalı daha güçlü ve etkin sonuçlar verebilen bir eşbütünleşme testi geliştirmişlerdir. Bu test için hesaplanan istatistikler denklem 3'te gösterilmektedir.

$$
\begin{aligned}
& \text { EG-JOH }=-2\left[\ln \left(\mathrm{p}_{\mathrm{EG}}\right)+\ln \left(\mathrm{p}_{\mathrm{JOH}}\right)\right] \\
& \text { EG-JOH-BO-BDM }=-2\left[\ln \left(\mathrm{p}_{\mathrm{EG}}\right)+\ln \left(\mathrm{p}_{\mathrm{JOH}}\right)+\ln \left(\mathrm{p}_{\mathrm{BO}}\right)+\ln \left(\mathrm{p}_{\mathrm{BDM}}\right)\right]
\end{aligned}
$$

Denklemde $p_{\mathrm{EG}}, \mathrm{p}_{\mathrm{JOH}}, \mathrm{p}_{\mathrm{BO}}$ ve $\mathrm{p}_{\mathrm{BDM}}$ bahsi geçen eş-bütünleşme testlerinin olasılık değerlerini vermektedir. EG-JOH sadece ilk iki testin, EG-JOH-BO$\mathrm{BDM}$ ise dört testin tamamının birleştirilmiş halidir. Bayer-Hanck eş-bütünleşme 
testinde bu testlerin olasılık değerleri Fisher formülü ile birleştirilmektedir. Analiz sonucunda hesaplanan Fisher istatistiği tablo kritik değerlerinden büyük olarak tespit edildiğinde eş-bütünleşmenin olmadığını ifade eden sıfır hipotezi reddedilerek incelenen değişkenler arasında uzun dönemli bir ilişkinin olduğu belirlenmektedir.

\subsection{FMOLS ve CCR Tahmincileri}

Phillips ve Hansen (1990)'in geliştirmiş oldukları tam değiştirilmiş en küçük kareler (FMOLS) yöntemi ile uzun dönem katsayıları tahmin edilirken kernel tahmincileri kullanarak yarı parametrik bir düzeltme uygulanmaktadır. FMOLS ile az sayıda gözleme sahip çalışmalarda da istikrarlı katsayılar elde edilebilmektedir. Ayrıca seriler birinci farkında I(1) durağan olduğunda kullanılan bu yöntemle otokolerasyon, içsellik ve modele dahil edilmeyen değişkenlerden kaynaklanabilecek olan problemler de giderilebilmektedir. FMOLS yöntemi için kurulan eşitlik denklem 4'te gösterilmektedir.

$$
\hat{\theta}=\left[\begin{array}{c}
\hat{\beta} \\
\hat{\gamma}_{1}
\end{array}\right]=\left(\sum_{\mathrm{t}=1}^{\mathrm{T}} \mathrm{Z}_{\mathrm{t}} \mathrm{Z}_{\mathrm{t}}\right)^{-1}\left(\sum_{\mathrm{t}=1}^{\mathrm{T}} \mathrm{Z}_{\mathrm{t}} \mathrm{Y}_{\mathrm{t}}^{+}-\mathrm{T}\left[\begin{array}{cc}
\lambda_{1}^{+} & 2 \\
0
\end{array}\right]\right)
$$

Denklemde $\hat{\theta}$ FMOLS tahmincisini, $\hat{\beta}$ eş-bütünleşme eşitliğinin katsayılarını, T gözlem sayısını, $\lambda_{12}^{+}$otokolerasyon ve içsellik gibi sapmalara sebebiyet veren problemleri düzeltme terimini, $Y_{t}^{+}$bağımlı değişkene uygulanan düzeltmeyi ifade etmektedir.

Park (1992) ise kanonik eş-bütünleşme regresyonu (CCR) tahmincisini geliştirmiştir. FMOLS yönteminde hem veri hem de parametre dönüşümü uygulanırken, CCR tahmincisinde sadece verilerin dönüşümü gerçekleştirilmektedir.

$$
\widehat{\vartheta}=\left[\begin{array}{c}
\hat{\beta} \\
\hat{\gamma}_{1}
\end{array}\right]=\left(\sum_{\mathrm{t}=1}^{\mathrm{T}} \mathrm{Z}_{\mathrm{t}}^{*} \mathrm{Z}_{\mathrm{t}}^{*}\right)^{-1} \sum_{\mathrm{t}=1}^{\mathrm{T}} \mathrm{Z}_{\mathrm{t}}^{*} \mathrm{Y}_{\mathrm{t}}^{*}
$$

CCR için kurulan eşitlik denklem 5 'te gösterilmektedir. Denklemde $\hat{\vartheta}$ CCR tahmincisini, T gözlem sayısını ifade etmektedir. CCR tahmincisindeki dönüşüm içselliği ortadan kaldırmakta ve asimptotik sapmaları telafi etmektedir. $\mathrm{Bu}$ nedenle FMOLS gibi CCR tahmincisi de tam etkindir.

\section{Ampirik Bulgular}

İlk olarak ampirik analiz gerçekleştirilmeden önce değişkenlere ait tanımlayıcı istatistikler incelenmiştir. Bu istatistikler tablo 1'de gösterilmektedir. Tabloda 0'a yakın eğiklik ve 2'ye yakın basıklık değerleri tüm değişkenlerin normal dağılıma sahip olduğunu belirtmektedir. Ayrıca Jarque-Bera testinin olasılık (p) değerleri de tüm seriler için normal dağılımın geçerli olduğunu belirten sıfir hipotezinin reddedilemediğini göstermektedir. Analize dahil edilecek olan tüm serilerin normal dağılıma sahip olduğu belirlenmiştir. Diğer bir önemli husus da ortalama ve ortanca arasında en fazla fark olan değiş̧ken INF'dir. Türkiye'de enflasyon oranı zaman içerisinde diğer değişkenlere göre daha fazla dalgalanmaktadır. $\mathrm{Bu}$ durum maksimum ve minimum değerlerinde de 
Finansal Gelişmenin Gelir Eşitsizliği Üzerindeki Etkileri: Finansal Kuznets Ĕgrisi Hipotezi Türkiye İçin Geçerli mi?

görülmektedir. Diğer değişkenler enflasyon oranına göre daha istikrarlı bir seyir izlemektedir.

Tablo 1: Değişkenlere Ait Tanımlayıcı İstatistikler

\begin{tabular}{|c|c|c|c|c|c|c|}
\hline Değişken & $\operatorname{lnGINI}$ & $\operatorname{lnFD} 1$ & $\operatorname{lnFD} 2$ & $\operatorname{lnINF}$ & $\operatorname{lnK}$ & $\operatorname{lnURB}$ \\
\hline Ortalama & 3,767 & 3,220 & 3,698 & 3,253 & 7,691 & 4,181 \\
\hline Ortanca & 3,781 & 2,970 & 3,708 & 3,732 & 7,568 & 4,184 \\
\hline Maksimum & 3,818 & 4,246 & 4,389 & 4,656 & 8,328 & 4,305 \\
\hline Minimum & 3,690 & 2,648 & 2,968 & 1,832 & 7,229 & 4,012 \\
\hline Std. Hata & 0,038 & 0,526 & 0,435 & 1,062 & 0,343 & 0,082 \\
\hline Eğiklik & $-0,669$ & 0,799 & 0,039 & $-0,128$ & 0,504 & $-0,261$ \\
\hline Basıklık & 2,268 & 2,150 & 1,781 & 1,195 & 1,904 & 2,101 \\
\hline Jarque Bera & 2,909 & 4,098 & 1,862 & 4,153 & 2,772 & 1,351 \\
\hline p-değeri & 0,233 & 0,128 & 0,394 & 0,125 & 0,250 & 0,508 \\
\hline
\end{tabular}

Değişkenler arasındaki eş-bütünleşme ilişkisini inceleyebilmek için bu çalışmada kullanılan yaklaşımda analize dahil edilen tüm değişkenlerin birinci farkında durağan I(1) olması gerekmektedir. Bu nedenle tanımlayıcı istatistikler belirtildikten sonra çalışmada Phillips ve Perron (1988) tarafından geliştirilen geleneksel PP birim kök testi ve az sayıda gözlem içeren verilerde etkin sonuçlar verebilen, genelleştirilmiş en küçük kareler yöntemine dayanan, Elliot vd. (1996) tarafindan geliştirilmiş Dickey-Fuller generalized least square (DF-GLS) birim kök testi kullanılarak değişkenlerin durağanlık düzeyleri sınanmıştır. Yapısal kırılmaları modellemeye dahil etmeyen bu iki birim kök testine ait bulgular tablo 2'de gösterilmektedir.

Tablo 2: Yapısal Kırılmasız Birim Kök Testlerinin Sonuçları

\begin{tabular}{|c|c|c|c|c|c|c|}
\hline \multicolumn{4}{|c|}{ PP } & \multicolumn{3}{|c|}{ DF-GLS } \\
\hline Değişken & Sabit & Sabit+trend & $\mathrm{b}$ & Sabit & Sabit+trend & $\mathrm{k}$ \\
\hline lnGINI & -1.057 & -2.594 & $0 / 1$ & $-1,064$ & $-2,514$ & $0 / 0$ \\
\hline lnFD1 & 0.441 & -1.522 & $1 / 0$ & 0,474 & $-1,303$ & $0 / 0$ \\
\hline $\operatorname{lnFD2}$ & 0.468 & $-9.429 * * *$ & $19 / 25$ & 0,417 & $-1,333$ & $0 / 0$ \\
\hline $\operatorname{lnINF}$ & -0.396 & -2.383 & $0 / 0$ & $-0,400$ & $-1,909$ & $0 / 0$ \\
\hline $\ln K$ & -0.385 & -2.337 & $2 / 1$ & $-0,310$ & $-2,347$ & $0 / 0$ \\
\hline $\operatorname{lnURB}$ & $-3.288 * *$ & $-8.814 * * *$ & $3 / 1$ & $-1,176$ & 0,514 & $4 / 4$ \\
\hline $\ln \Delta \mathrm{GINI}$ & $-5.674 * * *$ & $-5.544 * * *$ & $4 / 4$ & $-4,669 * * *$ & $-5,459 * * *$ & $0 / 0$ \\
\hline $\ln \Delta \mathrm{FD} 1$ & $-4.111 * * *$ & $-4.250 * *$ & $2 / 4$ & $-3,509 * * *$ & $-4,365 * * *$ & $0 / 0$ \\
\hline $\ln \Delta \mathrm{FD} 2$ & - & - & - & $-3,546 * * *$ & $-4,402 * * *$ & $0 / 0$ \\
\hline $\ln \Delta \mathrm{INF}$ & $-5.368 * * *$ & $-5.227 * * *$ & $2 / 2$ & $-1,982 * * *$ & $-4,920 * * *$ & $1 / 0$ \\
\hline $\ln \Delta \mathrm{K}$ & $-5.663 * * *$ & $-6.104 * * *$ & $3 / 5$ & $-5,748 * * *$ & $-5,871 * * *$ & $0 / 0$ \\
\hline $\ln \Delta U R B$ & - & - & - & $-1,345$ & $-3,193 * *$ & $0 / 3$ \\
\hline
\end{tabular}

Not: *** \%1 ve ** \%5 anlamlılık düzeylerinde serilerin birim kök içerdiğini belirten sıfır hipotezinin reddedildiğini göstermektedir. k: x/y sırasıyla DF-GLS birim kök testinde sabitli ve sabitli+trendli modeller için SIC bilgi kriteri ile belirlenen optimal gecikme uzunluklarını ifade etmektedir. b ise PP testinde Newey-West yaklaşımı ile belirlenen optimal bant genişliğini belirtmektedir. 
Tablo 2'de gösterilen bulgulara göre PP testinde FD2 ve URB değişkenleri seviye değerinde durağan tespit edilmiştir. Geriye kalan tüm değişkenler PP testinde birinci farkında durağandır. DF-GLS birim kök testi sonuçlarına göre ise bütün değişkenler seviye değerlerinde birim kök içermekte iken birinci farkında I(1) durağan olarak tespit edilmiştir. Makroekonomik serilerin stokastik özellikleri olumlu ve olumsuz şoklara karşı değişebilmektedir. Bu şokların etkilerini dikkate almamak birim kök ve durağanlığın yanlış belirlenmesine sebebiyet verebilir. Bu nedenle çalışmada ayrıca içsel olarak belirlenen tek bir yapısal kırılmaya izin veren Lee ve Strazicich (2013)'in geliştirdiği ve yazarların baş harfleri ile nitelendirilen LS birim kök testi de kullanılmıştır. Tablo 3'te gösterilen LS birim kök testinin sonuçlarına göre DF-GLS birim kök testinin sonuçları ile uyumlu olarak analize dahil edilecek olan bütün serilerin birim kök içerdiği, bu serilerin birinci farkında durağan olduğu tespit edilmiştir.

Tablo 3: LS Birim Kök Testlerinin Sonuçları

\begin{tabular}{|l|l|l|l|l|l|}
\hline Değişken & Model A & Model C & $\mathrm{k}$ & \multicolumn{2}{|c|}{ Kırılma Tarihi } \\
\hline $\ln$ GINI & -3.105 & -2.855 & $2 / 1$ & 2013 & 2013 \\
\hline $\ln$ FD1 & -1.963 & -3.830 & $4 / 1$ & 1999 & 2005 \\
\hline $\ln$ FD2 & -2.363 & -3.641 & $0 / 3$ & 1994 & 1993 \\
\hline $\ln I N F$ & -2.077 & -3.846 & $4 / 4$ & 2008 & 2001 \\
\hline $\ln \mathrm{l}$ & -3.167 & -3.555 & $2 / 0$ & 2009 & 1998 \\
\hline $\ln \mathrm{RBB}$ & -1.775 & -2.896 & $1 / 4$ & 1995 & 2010 \\
\hline $\ln \Delta \mathrm{GINI}$ & $-5.944 * * *$ & $-5.773 * * *$ & $0 / 0$ & 1999 & 2003 \\
\hline $\ln \Delta \mathrm{FD} 1$ & $-5.090 * * *$ & $-4.789 * *$ & $0 / 0$ & 1995 & 2000 \\
\hline $\ln \Delta \mathrm{FD} 2$ & $-4.479 * * *$ & $-5.429 * * *$ & $0 / 2$ & 1993 & 2002 \\
\hline $\ln \Delta \mathrm{INF}$ & $-4.541 * * *$ & $-5.984 * * *$ & $0 / 2$ & 1997 & 2006 \\
\hline $\ln \Delta \mathrm{K}$ & $-5.590 * * *$ & $-4.655 * *$ & $0 / 3$ & 1995 & 1998 \\
\hline $\ln \Delta \mathrm{URB}$ & $-4.317 * * *$ & $-5.776 * * *$ & $5 / 5$ & 1999 & 1998 \\
\hline
\end{tabular}

Not: *** \%1 ve ** \%5 anlamlılık düzeylerinde serilerin birim kök içerdiğini belirten sıfır hipotezinin reddedildiğini göstermektedir. Model A sabitte, Model C sabit ve trendde kırılmaya imkan vermektedir. Uygun gecikme uzunlukları gtos ile belirlenmiştir

Tüm değişkenlerin I(1) olduğu belirlendikten sonra uzun dönemli ilişkilerin tespiti için Bayer-Hanck eş-bütünleşme testi kullanılmıştır. Bu test uygulanırken ilk olarak optimal gecikme uzunluğunun belirlenmesi gerekmektedir. Optimal gecikme uzunluğu tespitinin sonuçları tablo 4'te gösterilmektedir.

Tablo 4: Eş-bütünleşme Testi için Optimal Gecikme Uzunlukları

\begin{tabular}{|l|l|l|l|l|l|}
\hline Model 1 & LogL & FPE & AIC & SIC & HQ \\
\hline 0 & 117,367 & $1,05 \mathrm{e}-11$ & $-8,249$ & $-7,961$ & $-8,1638$ \\
\hline 1 & 323,923 & $\mathbf{3 , 6 9 e - 1 7 *}$ & $-20,883$ & $\mathbf{- 1 8 , 8 6 7 *}$ & $-20,283$ \\
\hline 2 & 363,559 & $4,42 \mathrm{e}-17$ & $-21,152$ & $-17,409$ & $-20,039$ \\
\hline 3 & 420,291 & $4,39 \mathrm{e}-17$ & $\mathbf{- 2 2 , 6 8 8 *}$ & $-17,216$ & $\mathbf{- 2 1 , 0 6 1 *}$ \\
\hline
\end{tabular}


Finansal Gelişmenin Gelir Eşitsizliği Üzerindeki Etkileri: Finansal Kuznets Ĕgrisi Hipotezi Türkiye İçin Geçerli mi?

Tablo 4: Eş-bütünleşme Testi için Optimal Gecikme Uzunlukları

\begin{tabular}{|l|l|l|l|l|l|}
\hline Model 2 & LogL & FPE & AIC & SIC & HQ \\
\hline 0 & 121,150 & $7,96 \mathrm{e}-12$ & $-8,529$ & $-8,241$ & $-8,444$ \\
\hline 1 & 325,430 & $\mathbf{3 , 3 0 e - 1 7 *}$ & $-20,994$ & $\mathbf{- 1 8 , 9 7 9 *}$ & $-20,395$ \\
\hline 2 & 367,264 & $3,36 \mathrm{e}-17$ & $-21,426$ & $-17,683$ & $-20,313$ \\
\hline 3 & 421,194 & $4,11 \mathrm{e}-17$ & $\mathbf{- 2 2 , 7 5 5 *}$ & $-17,283$ & $\mathbf{- 2 1 , 1 2 8 *}$ \\
\hline
\end{tabular}

Not: * ilgili bilgi kriterine göre belirlenen optimal gecikme uzunluğunu göstermektedir.

Tabloya göre FPE ve SIC bilgi kriterleri uygun gecikme uzunluğunun 1, AIC ve HQ bilgi kriterleri ise 3 olduğunu göstermektedir. Her iki model için de benzer sonuç elde edilmiştir. Eş-bütünleşme testi için uygun gecikme uzunluğu SIC bilgi kriterine dayanarak 1 olarak ele alınmıştır.

Tablo 5'te gösterilen Bayer-Hanck testine ait sonuçlara göre model 1 için her iki test istatistiğinin de \%1 kritik değerlerden yüksek olduğu görülmektedir. Bu nedenle model 1'de özel sektöre bankalar sağlanan yerel kredilerin GSYH içindeki payı, gelir eşitsizliği, kentleşme, sermaye stoku ve enflasyon arasında uzun dönemli bir ilişki söz konusudur. Finansal gelişmenin özel sektöre sağlanan toplam yerel kredilerin GSYH içerisindeki payı olarak ifade edilen model 2 için de \%1 anlamlılık düzeyinde değişkenler arasında eş-bütünleşme ilişkisinin olduğu tespit edilmiştir.

Tablo 5: Bayer-Hanck Eş-bütünleşme Testinin Sonuçları

\begin{tabular}{|c|c|c|c|}
\hline \multicolumn{2}{|c|}{ Model 1 } & \multicolumn{2}{c|}{ Model 2 } \\
\hline EG- JO & EG-JO-BO-BDM & EG- JO & EG- JO -BO-BDM \\
\hline $21,846^{* * *}$ & $132,371^{* * *}$ & $20,015^{* * *}$ & $130,539^{* * *}$ \\
\hline Tablo kritik değerleri & $\% 1$ & $\% 5$ & $\% 10$ \\
\hline EG-J & 15,701 & 10,419 & 8,242 \\
\hline EG-J-BO-BDM & 29,850 & 19,888 & 15,804 \\
\hline
\end{tabular}

Not: ***: \%1 anlamlılık düzeyinde değişkenler arasında eş-bütünleşme ilişkisinin olduğunu belirtmektedir.

Bayer-Hanck eş-bütünleşme testine ait bulguların geçerliliğini teyit etmek amaciyla ayrıca dört test istatistiğinden birini sağlayan geleneksel Johansen (1988) eş-bütünleşme testi kullanılmıştır. Her iki model için gerçekleştirilen JO eş-bütünleşme testine ait bulgular tablo 6'da sunulmuştur.

Tabloda gösterilen sonuçlarda model 1 için iz istatistiğine göre $\% 5$ anlaml1l1k düzeyinde en az 3, en büyük öz-değer istatistiğine göre ise en az bir eş-bütünleşik vektör bulunmaktadır. Model 2 için elde edilen sonuçlar incelendiğinde ise iz istatistiğine göre $\% 5$ anlamlılık düzeyinde en az 4 , en büyük öz-değer istatistiğine göre ise en az 2 eş-bütünleşik vektörün olduğu görülmektedir. Bayer-Hanck eş-bütünleşme testinde dikkate alınan JO testinin sonuçlarına göre de eş-bütünleşmenin varlığı doğrulanmıştır. 
Tablo 6: Johansen Eş-bütünleşme Testinin Sonuçlart

\begin{tabular}{|l|l|l|l|l|l|}
\hline Model & $\mathrm{H}_{0}$ hipotezi & İz-istatistiği & $\begin{array}{l}\text { \%5 kritik } \\
\text { değer }\end{array}$ & $\begin{array}{l}\text { En büyük öz- } \\
\text { değer istatistiği }\end{array}$ & $\begin{array}{l}\text { \%5 kritik } \\
\text { değer }\end{array}$ \\
\hline \multirow{5}{*}{ Model 1 } & $\mathrm{r}=0$ & $135,093^{* * *}$ & 95,753 & $56,015^{* * *}$ & 40,077 \\
\cline { 2 - 6 } & $\mathrm{r} \leq 1$ & $79,077^{* * *}$ & 69,818 & 29,177 & 33,876 \\
\cline { 2 - 6 } & $\mathrm{r} \leq 2$ & $49,899^{* *}$ & 47,856 & 23,493 & 27,584 \\
\cline { 2 - 6 } & $\mathrm{r} \leq 3$ & 26,406 & 29,797 & 14,564 & 21,131 \\
\cline { 2 - 6 } & $\mathrm{r} \leq 4$ & 11,841 & 15,494 & 11,671 & 14,264 \\
\cline { 2 - 6 } & $\mathrm{r} \leq 5$ & 0,170 & 3,841 & 0,170 & 3,841 \\
\hline \multirow{5}{*}{ Model 2 } & $\mathrm{r}=0$ & $136,244^{* * *}$ & 95,753 & $41,833^{* *}$ & 40,077 \\
\cline { 2 - 6 } & $\mathrm{r} \leq 1$ & $94,410^{* * *}$ & 69,818 & $37,429 * *$ & 33,876 \\
\cline { 2 - 6 } & $\mathrm{r} \leq 2$ & $56,980^{* * *}$ & 47,856 & 23,127 & 27,584 \\
\cline { 2 - 6 } & $\mathrm{r} \leq 3$ & $33,852^{* *}$ & 29,797 & 19,933 & 21,131 \\
\cline { 2 - 6 } & $\mathrm{r} \leq 4$ & 13,919 & 15,494 & 10,201 & 14,264 \\
\cline { 2 - 6 } & $\mathrm{r} \leq 5$ & 3,717 & 3,841 & 3,717 & 3,841 \\
\hline
\end{tabular}

Not: ***: \%1 ve ** \%5 anlamlılık düzeyinde değişkenler arasında eş-bütünleşme ilişkisinin olduğunu belirtmektedir.

Değişkenler arasında eş-bütünleşmenin varlığı belirlendikten sonra son olarak uzun dönem katsayıları FMOLS ve CCR yöntemleri ile tahmin edilmiştir. Tablo 7'de yer alan her iki tahmincinin sonuçlarına göre finansal gelişme değişkenlerine ait pozitif ve finansal gelişmenin karesi olan değişkenlere ait negatif ve \%1 düzeyinde istatistiksel olarak anlamlı olan katsayılar Türkiye için finansal Kuznets eğrisinin geçerli olduğu göstermektedir. Bu durumda finansal gelişme ile birlikte ilk olarak bireyler arasındaki geliş eşitsizliği artsa da belirli bir eşikten sonra finansal gelişme gelirin daha adaletli bir şekilde dağıtılmasını sağlamaktadır. Her iki finansal gelişme değişkeni için de bu durum doğrulanmıştır. Ancak finansal gelişme Türkiye'de çevre kirliliğinde artışa sebebiyet vermektedir (Pata, 2018a,b,c). Bu nedenle bir taraftan finansal gelişme ile gelir eşitsizliği azaltılırken, diğer taraftan sürdürülebilir bir büyüme için çevresel kaygıların da göz önünde bulundurulması gerekmektedir. Her iki açıdan etkin bir finansal gelişme politikası uygulanmalıdır.

Tablo 7: FMOLS ve CCR Uzun Dönem Tahmincilerinin Sonuçlart

\begin{tabular}{|l|l|l|l|l|}
\hline Tahminci & \multicolumn{2}{|c|}{ FMOLS } & \multicolumn{2}{c|}{ CCR } \\
\hline Değişken & Model 1 & Model 2 & Model 1 & Model 2 \\
\hline $\ln F D 1, \operatorname{lnFD} 2$ & $0,448^{* * *}$ & $0,509^{* * *}$ & $0,398^{* * *}$ & $0,407^{* * *}$ \\
\hline $\ln (\mathrm{FD} 1)^{2}, \ln (\mathrm{FD} 2)^{2}$ & $-0,074^{* * *}$ & $-0,084^{* * *}$ & $-0,067^{* * *}$ & $-0,071^{* * *}$ \\
\hline $\ln \mathrm{NF}$ & $0,009^{* *}$ & $0,008^{* *}$ & $0,009^{* *}$ & $0,011^{* *}$ \\
\hline $\ln \mathrm{N}$ & $0,082^{* * *}$ & $0,074^{* * *}$ & $0,095^{* * *}$ & $0,108^{* * *}$ \\
\hline $\ln \mathrm{RB}$ & $-0,213^{* * *}$ & $-0,202^{* * *}$ & $-0,240^{* * *}$ & $-0,244^{* * *}$ \\
\hline $\mathrm{C}$ & $3,347^{* * *}$ & $3,263 * * *$ & $3,446^{* * *}$ & $3,359^{* * *}$ \\
\hline \multirow{2}{*}{ Jarque-Bera } & 1,598 & 1,685 & 1,703 & 2,097 \\
& $(0,449)$ & $(0,430)$ & $(0,426)$ & $(0,350)$ \\
\hline
\end{tabular}

Not: Optimal gecikme uzunluğu SIC ile belirlenmiştir. *** ve ** sırasıyla $\% 1$ ve $\% 5$ düzeyinde elde edilen katsayıların istatistiksel olarak anlamlı olduğunu göstermektedir. 
Finansal Gelişmenin Gelir Eşitsizliği Üzerindeki Etkileri: Finansal Kuznets Ĕgrisi Hipotezi Türkiye İçin Geçerli mi?

Diğer kontrol değişkenlerine ait bulgular incelendiğinde ise FMOLS yöntemine göre enflasyon ve kişi başına düşen sermaye stokundaki \%1'lik bir artış gelir eşitsizliğini sırasıyla $\% 0,009$ ve $\% 0,082$ oranında arttırmaktadır. CCR yöntemi ile de benzer bulgular elde edilmiştir. Bu katsayılar çok büyük olmamakla birlikte enflasyon ve sermaye stokundaki artışların gelir dağılımını olumsuz yönde etkilediği söylenebilir. Enflasyondaki artış genel itibariyle yoksul kesimi varlıklı kesimden daha fazla etkilemektedir. Yoksul kesimin enflasyon artışı ile birlikte alım gücü düşmekte, bu durumda gelir eşitsizliği artmaktadır. Benzer şekilde sermaye stoku artışı ile sağlanan gelir tabana yayılmadığı sürece sermaye de gelir eşitsizliğini arttırmaktadır. Son olarak kentleşmede \%1'lik bir artış gelir eşitsizliğini \%0,202-\%0-244 oranında azaltmaktadır. Kentleşme finansal gelişmeden sonra gelir eşitsizliğinin azaltılması için bulgular ışığından önemli bir etkendir. Kentsel nüfustaki artış ile birlikte bireyler daha iyi iş imkanlarına erişebilmekte, kendilerini geliştirebilmekte, daha iyi eğitim alabilmekte ve daha yüksek gelir elde edebilmektedir. Bu durum ülkedeki gelir eşitsizliğinin azalmasını sağlayabilmektedir.

\section{Sonuc}

Gelir eşitsizliği toplumlarda huzursuzluğa sebebiyet veren etkenlerin başında gelmektedir. Huzursuz olan toplumlarda ise çeşitli sosyoekonomik sorunlar açığa çıkmaktadır. Bahsedilen sorunların giderilebilmesi için gelir dağglımdaki eşitsizliğe sebebiyet veren faktörlerin belirlenmesi ve gerekli önlemlerin alınması oldukça önemlidir. Bu çalışmada Türkiye'de finansal gelişme ile gelir eşitsizliği arasında ters- $U$ şeklinde bir ilişki olduğunu ifade eden finansal Kuznets eğrisinin geçerliliği test edilmiş̧tir. Bayer-Hanck kombine eşbütünleşme testi ile finansal gelişme, enflasyon, kentleşme, sabit sermaye stoku ve gelir eşitsizliği arasında eş-bütünleşme ilişkisinin bulunduğu belirlenmiştir. Değişkenler arasında eş-bütünleşmenin varlığı belirlendikten sonra FMOLS ve CCR tahmincileri ile uzun dönem katsayıları özel sektöre bankalar tarafindan sağlanan yerel kredilerin ve özel sektöre sağlanan toplam yerel kredilerin GSYH içerisindeki payları olmak üzere iki model için belirlenmiştir. Her iki modelde de finansal gelişme ile gelir eşitsizliği arasında ters-U şeklinde bir ilişki olduğu tespit edilmiştir. $\mathrm{Bu}$ durumda finansal gelişme ilk başta zengini daha zengin ederek gelir eşitsizliğini arttıran bir etkenken, ileriki aşamalarda yoksul insanların da gelir düzeyinin artmasına yardımcı olan bir araçtır. Elde edilen sonuçlar Türkiye için uzun dönemde finansal Kuznets eğrisi hipotezinin geçerli olduğunu ifade eden Destek vd. (2017)'nin bulgularını destekler niteliktedir.

Gerçekleştirilen analizdeki diğer değişkenlerden enflasyon ve sabit sermaye stokundaki artış gelir eşitsizliğini uzun dönemde arttırmakta, kentleşme ise gelir dağılımını olumlu yönde etkileyerek adaletsizliğin giderilmesine yardımcı olmaktadır. Bu nedenle gelir dağılımını daha eşit bir şekilde sağlamak için enflasyondaki yüksek artışların önlenmesi, sermaye stokunun sadece tek bir 
kesime değil tabana da yayılmasının sağlanması ve altyapısal olarak daha güçlü kentlerin oluşturulması gerekmektedir.

Sonuçları genelleyecek olursak Türkiye'de gelir eşitsizliğinin azaltılması için kentleşmenin ve finansal gelişmenin güçlendirilerek devam etmesi gerekmektedir. Yoksul ile zengin arasındaki uçurumun giderilmesi için finansal kaynakların tüm kesimlerin erişebileceği ve faydalanabileceği bir şekilde geliştirilmesi şarttır. Bu nedenle hükümetin faaliyette bulunan finansal firma sayısının artması için gerekli zemini hazırlaması ve bu firmalar arasındaki rekabeti kuvvetlendirerek finansal sektörün gelişimine destek olması gerekmektedir.

\section{Kaynaklar}

ALTINTAŞ, H., AYRIÇAY, Y. (2010), Türkiye'de Finansal Gelişme ve Ekonomik Büyüme İlişkisinin Sınır Testi Yaklaşımıyla Analizi: 19872007, Anadolu Üniversitesi Sosyal Bilimler Dergisi, 10 (2), 71-98.

ANG, J. B. (2010), Finance and Inequality: the Case of India, Southern Economic Journal, 76 (3), 738-761.

ARGUN, A. İ. (2016), Gelişmekte Olan Ülkelerde Finansal Gelişme ve Gelir Eşitsizliği, Istanbul Üniversitesi Sosyal Bilimler Dergisi, 1, 61-74.

ASLAN, Ö., KÜÇÜKAKSOY, İ. (2006), Finansal Gelişme ve Ekonomik Büyüme İlişkisi: Türkiye Ekonomisi Üzerine Ekonometrik Bir Uygulama, Ekonometri ve İstatistik E-Dergisi, 4, 25-38.

AZAM, M., RAZA, S. A. (2018), Financial Sector Development and Income Inequality in ASEAN-5 Countries: Does Financial Kuznets Curve Exists?, Global Business and Economics Review, 20 (1), 88-114.

BALIGH, N., PIRAEE, K. (2012), Financial Development and Income Inequality Relationship in Iran, Middle-East Journal of Scientific Research, 12 (7), 906-914.

BANERJEE, A. V., NEWMAN, A. F. (1993), Occupational Choice and the Process of Development, Journal of Political Economy, 101 (2), 274-298.

BANERJEE, A., DOLADO, J., MESTRE, R. (1998), Error-Correction Mechanism Tests for Cointegration in a Single-Equation Framework, Journal of Time Series Analysis, 19 (3), 267-283.

BATUO, M., MLAMBO, K., GUIDI, F. (2010), Financial Development and Income Inequality: Evidence from African Countries, MPRA Paper No 25658. 10 Kasim 2019 tarihinde http://mpra.ub.uni-muenchen.de/25658 adresinden alınd.

BAYER, C., HANCK, C. (2013), Combining Non-Cointegration Tests, Journal of Time Series Analysis, 34 (1), 83-95.

BOSWIJK, H. P. (1994), Testing for an Unstable Root in Conditional and Structural Error Correction Models, Journal of Econometrics, 63 (1), 3760. 
Finansal Gelişmenin Gelir Eşitsizliği Üzerindeki Etkileri: Finansal Kuznets Ĕgrisi Hipotezi Türkiye İçin Geçerli mi?

CANAVIRE-BACARREZA, G., RIOJA, F. (2008), Financial Development and the Distribution of Income in Latin America and the Caribbean, (No. 3796). IZA Discussion Papers. 10 Kasim 2019 tarihinde https://www.econstor.eu/bitstream/10419/35601/1/584662637.pdf adresinden alındi.

CLARKE, G. R., XU, L. C., ZOU, H. F. (2006), Finance and Income Inequality: What Do the Data Tell Us?, Southern Economic Journal, 72 (3), 578-596.

COBBINAH, P. B., ERDIAW-KWASIE, M. O., AMOATENG, P. (2015), Rethinking Sustainable Development within the Framework of Poverty and Urbanisation in Developing Countries, Environmental Development, $13,18-32$.

DEMIRGUÇ-KUNT, A., Levine, R. (2009), Finance and Inequality: Theory and Evidence, Annual Review of Financial Economics, 1 (1), 287-318.

DESTEK, M. A., OKUMUŞ, İ., MANGA, M. (2017), Türkiye'de Finansal Gelişim ve Gelir Dağılımı İlişkisi: Finansal Kuznets Eğrisi, Doğuş Üniversitesi Dergisi, 18 (2), 153-165.

DOGAN, B. (2018), The Financial Kuznets Curve: A Case Study of Argentina, The Empirical Economics Letters, 17 (4), 527-536.

DÜNYA BANKASI KALKINMA GÖSTERGELERİ (2019), 10 Kasım 2019 tarihinde https://data.worldbank.org/ country/turkey adresinden alındı

ELLIOTT, G., ROTHENBERG, T., STOCK, J. H. (1996), Efficient Tests for an Autoregressive Unit Root, Econometrica, 64, 813-839.

ENGLE, R. F., GRANGER, C. W. (1987), Co-integration and Error Correction: Representation, Estimation, and Testing, Econometrica: Journal of the Econometric Society, 55 (2), 251-276.

FISHER, R. A. (1932), Statistical Methods for Research Workers, In: Breakthroughs in Statistics, New York: Springer.

GALOR, O., ZEIRA, J. (1993), Income Distribution and Macroeconomics, The Review of Economic Studies, 60 (1), 35-52.

GREENWOOD, J., JOVANOVIC, B. (1990), Financial Development, Growth, and the Distribution of Income, Journal of Political Economy, 98 (5), 1076-1107.

HEPSAĞ, A. (2017), Finansal Kuznets Eğrisi Hipotezi: G-7 Ülkeleri Örneği, Sosyal Güvenlik Dergisi, 7 (2), 135-156.

HOI, L. Q., HOI, C. M. (2013), Financial Sector Development and Income Inequality in Vietnam: Evidence at the Provincial Level, Journal of Southeast Asian Economies, 30 (3), 263-277.

JAUCH, S., WATZKA, S. (2016), Financial Development and Income Inequality: A Panel Data Approach, Empirical Economics, 51, 291-314.

JOHANSEN, S. (1988), Statistical Analysis of Cointegration Vectors, Journal of Economic Dynamics and Control, 12 (2), 231-254.

KUZNETS, S. (1955), Economic Growth and Income Inequality, The American Economic Review, 45 (1), 1-28. 
LEE, J., STRAZICICH, M. (2013), Minimum LM Unit Root Test with One Structural Break. Economics Bulletin, 33 (4), 2483-2492.

MACHADO, D. B., RASELLA, D., DOS SANTOS, D. N. (2015), Impact of income Inequality and Other Social Determinants on Suicide Rate in Brazil, PLoS One, 10 (4), e0124934.

MOOSA, I. (2016), International Evidence on the Financial Kuznets Curve, International Economics, 69 (4), 361-374.

NIKOLOSKI, Z. (2013), Financial Sector Development and Inequality: Is There a Financial Kuznets Curve?, Journal of International Development, 25, 897-911.

PANAYOTOU, T. (1993), Empirical Tests and Policy Analysis of Environmental Degradation at Different Stages of Economic Development, ILO, Technology and Employment Programme, Geneva. 10 Kasim 2019 tarihinde https://www.ilo.org/public/libdoc/ilo/1993/ 93B09_31_engl.pdf adresinden alınd1.

PARK, J. Y. (1992), Canonical Cointegrating Regressions, Econometrica: Journal of the Econometric Society, 60 (1), 119-143.

PATA, U. K., ALPEREN, A. (2018), Finansal Gelişme ve Ekonomik Büyüme Arasındaki Eşbütünleşme ve Nedensellik İlişkisi: Türkiye Örneği, Osmaniye Korkut Ata Üniversitesi İktisadi ve İdari Bilimler Fakültesi Dergisi, 2 (2), 115-128.

PATA, U. K. (2018a), Renewable Energy Consumption, Urbanization, Financial Development, Income and $\mathrm{CO}_{2}$ Emissions in Turkey: Testing EKC Hypothesis with Structural Breaks. Journal of Cleaner Production, 187, 770-779.

PATA, U. K. (2018b), The Influence of Coal and Noncarbohydrate Energy Consumption on $\mathrm{CO}_{2}$ Emissions: Revisiting the Environmental Kuznets Curve Hypothesis for Turkey, Energy, 160, 1115-1123.

PATA, U. K. (2018c), The Effect of Urbanization and Industrialization on Carbon Emissions in Turkey: Evidence from ARDL Bounds Testing Procedure, Environmental Science and Pollution Research, 25 (8), 77407747.

PHILLIPS, P. C., PERRON, P. (1988), Testing for a Unit Root in Time Series Regression. Biometrika, 75(2), 335-346.

PHILLIPS, P. C., HANSEN, B. E. (1990), Statistical Inference in Instrumental Variables Regression with I(1) Processes, The Review of Economic Studies, 57 (1), 99-125.

REHMAN, H., KHAN, S., AHMED, I. (2008), Income Distribution, Growth and Financial Development: A Cross Countries Analysis, Pakistan Economic and Social Review, 46 (1), 1-16.

SATTI, S. L., MAHALIK, M. K., BHATTACHARYA, M., SHAHBAZ, M. (2015), Dynamics of Income Inequality, Finance and Trade in Kazakhstan: Empirical Evidence from a New Transition Economy with Policy 
Finansal Gelişmenin Gelir Eşitsizliği Üzerindeki Etkileri: Finansal Kuznets Ĕgrisi Hipotezi Türkiye İçin Geçerli mi?

Prescriptions, Monash Business School, Department of Economics Discussion Paper, No. 36/15. 10 Kasim 2019 tarihinde https://www.monash.edu/_data/assets/pdf_file/0008/925649/dynamics of_income_inequality,_finance_and_trade_in_kazakhstan_empirical_evid ence_from_a_new_transition_economy_with_policy_prescriptions.pde adresinden alındi.

SEHRAWAT, M., GIRI, A. K. (2015), Financial Development and Income Inequality in India: An Application of ARDL Approach, International Journal of Social Economics, 42 (1), 64-81.

SHAHBAZ, M., LOGANATHAN, N., TIWARI, A. K., SHERAFATIANJAHROMI, R. (2015), Financial Development and Income Inequality: Is There any Financial Kuznets Curve in Iran?, Social Indicators Research, 124 (2), 357-382.

SOLT, F. (2018), The Standardized World Income Inequality Database. Social Science Quarterly. $10 \quad$ Kasim 2019 tarihinde https://dataverse.harvard.edu/file.xhtml?file $\quad \mathrm{Id}=3207292 \&$ version $=20.0$ adresinden alınd.

TAN, H. B., LAW, S. H. (2012), Nonlinear Dynamics of the Finance-Inequality Nexus in Developing Countries, The Journal of Economic Inequality, 10 (4), 551-563.

TIWARI, A. K., SHAHBAZ, M., ISLAM, F. (2013), Does Financial Development Increase Rural-Urban Income Inequality? Cointegration Analysis in the Case of Indian Economy, International Journal of Social Economics, 40 (2), 151-168.

TOPUZ, S. G., DAĞDEMIR, Ö. (2016), Finansal Gelişme ve Gelir Eşitsizliği: Bir Panel Veri Analizi”, Anadolu Üniversitesi Sosyal Bilimler Dergisi, 16(3), 19-34.

VAN VELTHOVEN, A., DE HAAN, J., STURM, J. E. (2019), Finance, income inequality and income redistribution, Applied Economics Letters, 26 (14), 1202-1209.

YOUNSI, M., BECHTINI, M. (2018), Economic Growth, Financial Development, and Income Inequality in BRICS Countries: Does Kuznets' Inverted U-Shaped Curve Exist?, Journal of the Knowledge Economy, 122. $11 \quad$ Kasim $2019 \quad$ tarihinde https://link.springer.com/article/10.1007/s13132-018-0569-2 adresinden alınd. 